\title{
Reveal Cytotoxicity and Antigenotoxicity of Piper nigrum L. Ethanolic Extract and its Combination with Doxorubicin on CHO-KI Cells
}

\author{
Nur Fitra Sari ${ }^{1}$, Beni Lestari ${ }^{1}$, Dian Saputri ${ }^{1}$, Anisa Fauzia Ahsani ${ }^{1}$, \\ Ragil Anang Santoso ${ }^{1}$, Ediati Sasmito ${ }^{2}$, Edy Meiyanto ${ }^{1,2}$ \\ ${ }^{1}$ Cancer Chemoprevention Research Center, Faculty of Pharmacy, Universitas Gadjah Mada, Yogyakarta, Indonesia \\ ${ }^{2}$ Department of Pharmaceutical Chemistry, Faculty of Pharmacy, Universitas Gadjah Mada, Yogyakarta, Indonesia
}

\begin{abstract}
Black pepper (Piper nigrum L.), one of the most popular Indonesian spices has been reported to possess various therapeutic effects. The aim of this study is to evaluate the cytotoxicity and antigenotoxicity of black pepper ethanolic extract (BPE) and its combination with doxorubicin (Dox) on CHO-KI cells. Based on thin layer chromatography analysis, BPE contained piperine. Under MTT assay, BPE showed cytotoxic effect with the $I_{50}$ value of $68 \mu \mathrm{g} / \mathrm{mL}$ and performed synergism in combination with Dox. In vitro micronucleus test using Giemsa staining revealed that BPE did not cause morphological changes qualitatively on CHO-KI cells at concentration of $8.5 \mu \mathrm{g} / \mathrm{mL}$, whereas using flow cytometry analysis showed that BPE could decrease the number of micronucleus (MN) formation induced by doxorubicin. In addition, BPE reduced the ROS level on the CHO-KI cells which observed by reactive oxygen species (ROS) intracellular assay. The decrease in ROS level indicated that the antioxidant activity of BPE contribute to the antigenotoxicity. Furthermore, molecular docking performed that piperine interacted with DNA Topoisomerase II with docking score of -80.68 . Overall, BPE performed cytotoxic effect in single treatment, increased the cytotoxicity and reduced the genotoxicity of doxorubicin. Thus, BPE has potential to be developed further as co-chemotherapeutic and antigenotoxic agent.
\end{abstract}

Keywords: Cytotoxic, genotoxic, Piper nigrum L., CHO-KI, micronucleus

\section{INTRODUCTION}

Spices are common food ingredient consumed by Asian people to make several foods taste better. One of the most famous spices with its distinctive spicy flavor and aroma is black pepper (Piper nigrum L.) that is widely cultivated in tropical countries such as Indonesia (Damanhouri and Ahmad, 2014). Alongside being a supplementary ingredient in food, the community empirically has utilized black pepper as a body warmer, stamina enhancer, and one of the components in traditional medicine (Ahmad, et al., 2012). Particularly, in the field of drug development, the exploration of the medical benefits of this spice becomes a challenge.

Black pepper is known to contain piperine or 1-peperoyl piperidine (Fig. 1a) as the major compound which the first active compound that isolated from different members of Piperaceae family and was found to possesss diverse pharmacological activities (Damanhouri and Ahmad,
2014). Piperine has been studied to have potentially various therapeutic activities such as antihypertensive and antiplatelets (Taqvi, et al., 2008), antiasthmatics (Parganiha, et al., 2011), antipyretic, analgesic, anti-in ammatory, antidiarrheal, antispasmodic, anxiolytic, antidepressants (Li, et al., 2007), hepatoprotective (Bajad et al., 2001), anti-inflammatory, antioxidant, antitumor (Manoharan, et al., 2009), immunomodulator, immunostimulant, antibacterial, antifungal, and may increase the bioavailability of the drug in the body (Meghwal, et al., 2013).

Although black pepper has been widely used routinely as a spice or herbal medicine, there has not been much evaluation of the genotoxicity of black pepper extract using $\mathrm{CHO}-\mathrm{K} 1$ cells as a common model for gentoxicity test.

*Corresponding author e-mail: edy_meiyanto@ugm.ac.id 
The genotoxicity of piperine has been investigated by several scientists; reverse mutation assays in Salmonella typhimurium (Ames Test) showed negative result (Andrews, et al., 1980). An in vitro micronucleus test using hepatoma cells (H4IIEC3/G-cells) was negative response (Singh, et al., 1994), while in vivo Comet assay in lungs of male mice (Selvendiran, et al., 2005) at concentration levels of up to $75 \mathrm{mg} / \mathrm{kg}$ bw performed no genotoxic activities. Piperine has also no genotoxic potential under MNT in vitro and in vivo evaluation (Thiel, et al., 2014). Therefore, this study convey information regarding to the antigenotoxicity of black pepper extract especially in combination with doxorubicin (Dox).

This study aims to evaluate the cytotoxic and antigenotoxic effects of black pepper ethanolic extract (BPE) through in vitro modeling system using the Chinese hamster ovary (CHO-K1) cells solely and its combination with Dox. CHO-K1 cells was exerted as a model of proliferative cells and Dox for modelling a genotoxic inducer. Genotoxic effect was analyzed by cytokinesis-block micronucleus (CBMN) assay through staining with Giemsa and counting the micronucleus formation. Moreover, we also measured reactive oxigen species (ROS) level using DCFDA reagent. The findings from this research can be useful for the development of BPE as co-chemotherapeutic agent overcoming the cytotoxicity of Dox.

\section{MATERIALS AND METHODS}

\section{Extract Preparation and Identification Chemical Compound of BPE}

Black pepper (Piper nigrum L.) powder form was obtained from Balai Materia Medika Batu, Malang, East Java and determined at the same place. Black pepper powder was macerated by ethanol p.a. (Merck) for 24 hours and concentrated by evaporating the solven. The identification of the chemical content in BPE was carried out using thin layer chromatography (TLC) with silica gel $60 \mathrm{~F}_{254}$ as the stationary phase and dichlorometan:ethyl acetate $(3: 1 \mathrm{v} / \mathrm{v})$ as the mobile phase. Spots were identified under UV $254 \mathrm{~nm}$ and UV $366 \mathrm{~nm}$.

\section{CHO-KI Cell Culture}

CHO-K1 cells were obtained from Prof. Masashi Kawaichi, Nara Institute of Science and Technology, Japan. The cells were cultured in Rosewell Park Memorial Institute (RPMI) medium (Gibco) supplemented with $10 \%$ v $/ \mathrm{v}$ Fetal Bovine Serum (FBS) (Sigma), Fungizone $1.25 \mu \mathrm{g} / \mathrm{mL}$ and $150 \mathrm{U} / \mathrm{mL}$ Penicillin - $150 \mu \mathrm{g} / \mathrm{mL}$ Streptomycin (Gibco) at $37^{\circ} \mathrm{C}$ and $5 \% \mathrm{CO}_{2}$. Trypsin-EDTA $0.25 \%$ (Gibco) was used to detach cells from tissue culture dish.

\section{Cytotoxicity Assay}

Cytotoxic assay was performed using MTT assay. Cells (briefly $8 \times 10^{3}$ cells/well) were transferred to 96-wellplate and then incubated for 24 hours. Cells were treated with BPE, Dox, and their combination and then incubated for 24 hours. After 24 hours, medium was removed and cells were washed with $100 \mathrm{~mL}$ of PBS. Then $100 \mathrm{~mL}$ of MTT reagent with final concentration of $0.5 \mathrm{mg} / \mathrm{mL}$ in medium was added into each well and incubated again for 4 hours to form formazan crystal. The stopper reagent $(10 \%$ SDS in $0.01 \mathrm{~N} \mathrm{HCl})$ was used to dissolve then the cell were incubated overnight at room temperature and in the dark (covered with alumunium foil). The next day, the absorbance from each well was measured by ELISA reader with 595 $\mathrm{nm}$ wavelength then converted to cells viability percent.

\section{ROS Intracellular Assay}

CHO-K1 cells (briefly $5 \times 10^{4}$ cells/well) were transferred into 24-wellplate and incubated for 24 hours. After 24 hours, medium was removed and cells were washed with PBS. Cells were detached using $200 \mu \mathrm{L}$ trypsin-EDTA per well. Trypsin was inactivated using $450 \mu \mathrm{L} 1 \mathrm{X}$ supplemented buffer per well. Cells were collected and transferred into microtube then stained with DCFDA $\left(2^{\prime}, 7^{\prime}\right.$ dichlorofluorescin diacetate) as much as $25 \mu \mathrm{M} /$ well and incubated for 30 minutes in $37^{\circ} \mathrm{C}$ incubator. After 30 minutes, cells were treated with BPE, doxorubicin and their combination and incubated for 4 hours. ROS analysis performed using flow cytometry at wavelength of Ex $485 \mathrm{~nm} / \mathrm{Em} 535 \mathrm{~nm}$. 


\section{CBMN Assay using Giemsa Staining}

CHO-K1 cells (briefly $1.2 \times 10^{4}$ cells $/$ well) were seeded on coverslips in 24-wellplate and incubated for 24 hours. Cells were treated with BPE, Dox, and their combination then incubated for 24 hours. After 24 hours, medium was removed and washed with $500 \mu \mathrm{L}$ of PBS per well. Cells were fixed with $500 \mu \mathrm{L}$ of cold hypotonic solution $(\mathrm{KCl}$ $0.075 \mathrm{M})$ and incubated for 6 minutes. The cold hypotonic solution was discarded then added $500 \mu \mathrm{L}$ of methanol:acetic acid (3:1) solution and incubated for 30 minutes. Cells were stained using $500 \mu \mathrm{L}$ of 5\% Giemsa and incubated for 1 hour. Coverslips were removed from wells to object glasses. Observation was performed under light microscope with 400x magnifications.

\section{CBMN Assay using Flow cytometry}

The genotoxic flow cytometry assay was performed as describe previously with slightly modification (Avlasevich, et al., 2006). CHO-K1 cells (briefly $5 \times 10^{4}$ cells/well) were seeded in 6wellplate and incubated for 24 hours. Then, cells were treated with various concentrations of BPE, Dox, and their combination and incubated for 24 hours. After 24 hours, cell medium was transferred into conical tube. Cells were washed with PBS of $500 \mu \mathrm{L}$ and placed in conical tube. As much as 200 $\mu \mathrm{L}$ of trypsin-EDTA was added and incubated for 3 minutes. Tripsin was inactivated by added $1 \mathrm{~mL}$ of medium. Cells suspension were transferred into conical tube and centrifuged at $1500 \mathrm{rpm}$ for 5 minutes. As much as $100 \mu \mathrm{L}$ of Nucleic Acid Dye Working Solution was added then soaked in ice and irradiated with a light source for 20 minutes. As much as $3 \mathrm{~mL}$ of cold buffer solution was added and placed in dark room. The cells were centrifuged at $1500 \mathrm{rpm}$ for 5 minutes. The supernatant was removed then the cell pellet was resuspended with 1 $\mathrm{mL}$ of Complete Lysis Solution 1 and incubated at room temperature for 1 hour. Lysis Solution 1 was prepared with aquabides, $0.584 \mathrm{mg} / \mathrm{mL} \mathrm{NaCl}, 1$ $\mathrm{mg} / \mathrm{mL}$ sodium citrate, $0.3 \mu \mathrm{L} / \mathrm{mL}$ IGEPAL, 1 $\mathrm{mg} / \mathrm{mL}$ Rnase A (Sigma) and $0.4 \mu \mathrm{L} / \mathrm{mL}$ SYTOX Green (Life Technologies). Furthermore, $1 \mathrm{~mL}$ of Complete Lysis Solution 2 was added and incubated at room temperature for 30 minutes. Lysis Solution 2 was prepared with aquabides, $85.6 \mathrm{mg} / \mathrm{mL}$ sucrose (Merck), $15 \mathrm{mg} / \mathrm{mL}$ citric acid (Merck), and 0.4 $\mu \mathrm{L} / \mathrm{mL}$ of SYTOX Green. Then, samples were analyzed using flow cytometer.

\section{Molecular Docking}

Molecular docking was performed to evaluate the interaction between piperine and DNA Topoisomerase II protein (PDB ID: 4GOV). Piperine structure was prepared using Marvin Sketch while DNA Topoisomerase protein was obtained from protein Data Bank (http://www.pdb.org/). Validation was done with parameter value of RMSD (Root Mean Square Distances) where RMSD value is must be less than $2 \AA$ (Purnomo, 2011). Docking was done using PLANTS software to obtain docking score. Docking score indicates the chemical bonding strength between ligand and receptor.

\section{RESULTS}

\section{Extraction and Identification of BPE Phytochemical Content}

From maceration, we gained viscous black pepper extract (BPE) of $6.89 \% \quad(\mathrm{w} / \mathrm{w})$ yield. Qualitative identification of the phytochemical content of BPE was performed by using TLC. The result showed that there was same spot between the piperine and BPE sample at $\mathrm{hRf}$ value of 82.5 which indicated similar polarity between chemical component of BPE and piperine standard (Fig. 1b). This phenomenon was predicted that BPE contained piperine as its chemical compound. 
(a)

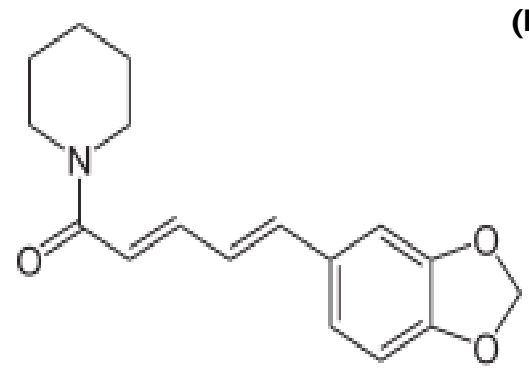

(b)

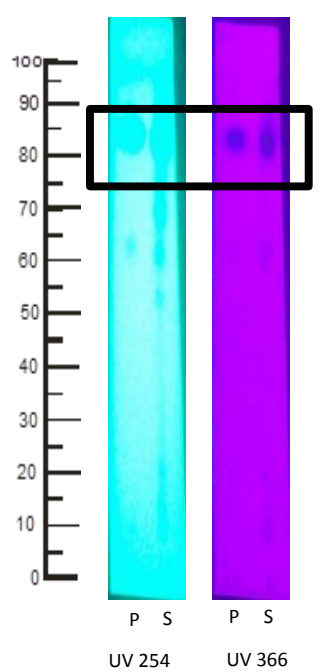

Figure I. Chemical structure and phytochemical profile of piperine in BPE. (a) Chemical structure of piperine as the major compound of BPE. (b) Chromatogram profile of piperine by thin layer chromatography (TLC). The elution was carried out with a silica gel $60 \mathrm{~F}_{254}$ as stationary phase and the dichloromethane:ethyl acetate $(3: 1 \mathrm{v} / \mathrm{v})$ as mobile phase with an elution distance of $8 \mathrm{~cm}$. Detection was performed under UV254 and UV366. (P: piperine standard; S:BPE sample).

\section{Effects of BPE and Its Combination With Dox on CHO-KI Cells Viabillity and Intracellular ROS Level}

Cytotoxic assay was performed using MTT Assay to determine the effect of BPE on CHO-K1 cells viability. The results indicated that BPE caused reduction of cells viability with $\mathrm{IC}_{50}$ value of 68 $\mu \mathrm{g} / \mathrm{mL}$ (Fig. 2). $\mathrm{IC}_{50}$ value was used as fundamental to determine concentration used in followed experiments.

Dox was used in combination treatment as one of chemotherapeutic agents that can cause cell toxicity through the mechanism of inhibition of DNA Topoisomerase II, intercalation with DNA causing inhibition of DNA synthesis, as well as the formation of free radicals of semiquinone and oxygen free radicals (Bruton, et al., 2005). Combination treatment of BPE and Dox was revealed by using BPE concentration of $8.5 \mu \mathrm{g} / \mathrm{mL}$ while the concentrations of doxorubicin used were 1 , 2 , and $4 \mu \mathrm{M}$. The combination could decrease cell viability greater than single treatment (Fig. 2b). In addition, the combination treatment has combination index (CI) value of $<1$ which indicated synergistic activity between BPE and Dox (Fig. 2c). These results suggested that BPE could be developed as a co-chemotherapeutic agent against cancer cells in order to improve the effectiveness of Dox.

ROS (Reactive Oxygen Species) intracellular assay was aimed to determine the ability of BPE in lowering ROS levels in CHO-K1 cells. The results showed decreasing in fluorescence intensity which indicated reducing of intracellular ROS in CHO-K1 cells (Fig. 2d). That phenomenon was probably due to the antioxidant activity of BPE. This result strengthened the potency of BPE as antigenotoxic agent by neutralizing radical compound which cause DNA damage. 
(a)

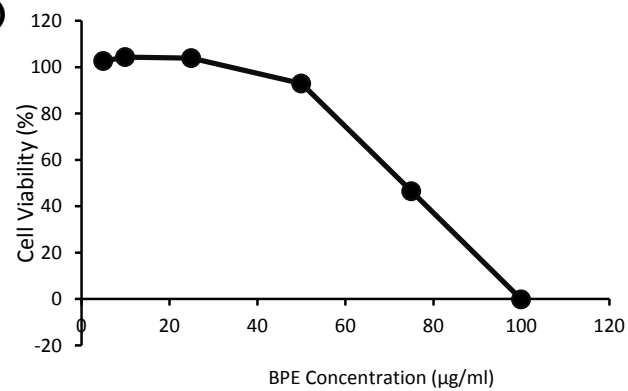

(c)

\begin{tabular}{cccc}
\multicolumn{3}{c}{ CI Values of Combination Treatment between BPE and Dox } \\
\hline \multirow{2}{*}{$\begin{array}{c}\text { Concentration of } \\
\text { BPE }(\boldsymbol{\mu g} / \mathrm{mL})\end{array}$} & \multicolumn{3}{c}{ Concentration of Dox $(\boldsymbol{\mu M})$} \\
\cline { 2 - 4 } & $\mathbf{1}$ & $\mathbf{2}$ & $\mathbf{4}$ \\
\hline $\mathbf{8 . 5}$ & 0.21 & 0.20 & 0.16 \\
\hline $\mathbf{1 7}$ & 0,41 & 0,01 & 0,00 \\
\hline
\end{tabular}

(b)

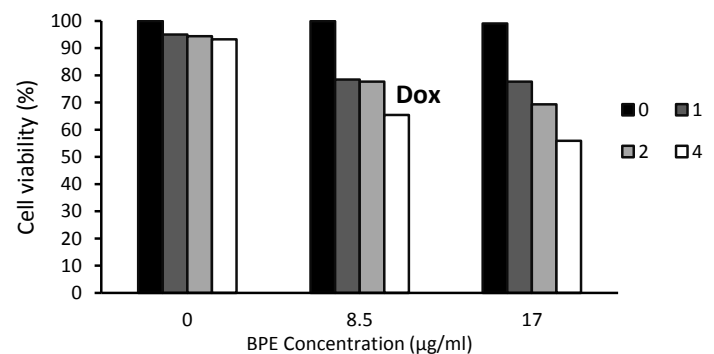

(d)

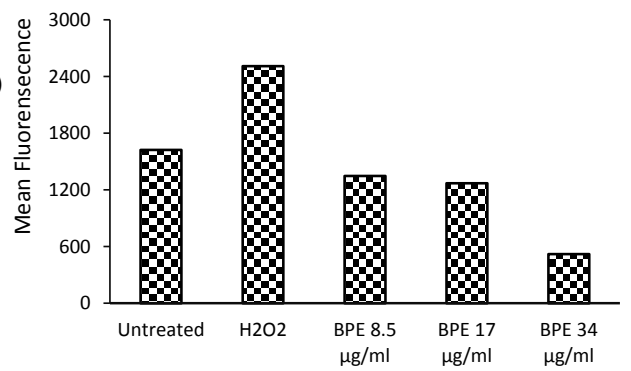

Figure 2. Effect of single treatment of BPE and the combination with Dox on cell viability and intracellular ROS levels on CHO-KI cells. Cytotoxic effect of BPE (a) and the combination with Dox (b and c) were conducted by MTT assay, $\mathrm{CHO}-\mathrm{KI}$ cells $\left(\mathrm{I} \times 10^{4}\right.$ cells/well) were treated with the compounds in the concentration as indicated for 24-h. The IC 50 values were important to the further assays and were calculated by using linear regression in three independent experiments. The intracellular ROS level of BPE was measured using flow cytometry with DCFDA staining. (d) Histograms of ROS-positive cell percentage by mean of DCF fluorescence intensity.

\section{Effects of BPE on Micronucleus Formation}

Micronucleus is one of parameter to determine genetic damage. Micronucleus would be expressed on imperfectly divided cells because of DNA damage. Damaged DNA is unable to reach the spindle string during mitosis. Therefore, in telophase stage, cells form nuclear membrane that would cover damaged DNA and form small nucleus called micronucleus (Fenech, 2000).

Based on qualitative observation of CBMN assay, Dox $1 \mu \mathrm{M}$ treatment showed micronucleus formation and changed in cell morphology while in BPE $8.5 \mu \mathrm{g} / \mathrm{mL}$ treatment, it was not found morphological changes. However, in the combination of BPE and Dox, the micronucleus formation was difficult to observe (Fig. 3a). These results qualitatively showed that low concentrations of BPE did not induce genotoxic in CHO-K1 cells.

Genotoxic assay using flowcytometry revealed that Dox $1 \mu \mathrm{M}$ did not induce micronucleus formation. However, doxorubicin $2 \mathrm{nM}$ showed micronucleus formation with MN percentage of $94.83 \%$ while BPE 17 and $34 \mu \mathrm{g} / \mathrm{mL}$ did not show micronucleus formation. In combination of Dox and BPE found that BPE could decrease the micronucleus percentage (Fig. 3b). This results suggested that BPE is potential as an antigenotoxic agent on CHO-K1 cells. 
(a)

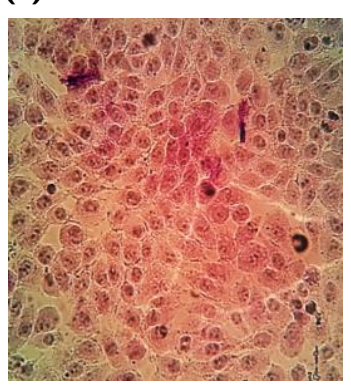

(b)

\begin{tabular}{lcc}
\hline Treatment & \% MN & \% Nucleus \\
\hline Untreated & 0,1 & 99,5 \\
Dox $1 \mu \mathrm{M}$ & 0 & 99,6 \\
Dox $2 \mu \mathrm{M}$ & 73,3 & 4 \\
BPE $17 \mu \mathrm{g} / \mathrm{mL}$ & 0 & 99,3 \\
BPE $34 \mu \mathrm{g} / \mathrm{mL}$ & 0 & 99,8 \\
Dox $1 \mu \mathrm{M}+$ BPE $17 \mu \mathrm{g} / \mathrm{mL}$ & 0,1 & 99,1 \\
Dox $1 \mu \mathrm{M}+$ BPE $34 \mu \mathrm{g} / \mathrm{mL}$ & 1 & 99,2 \\
Dox $2 \mu \mathrm{M}+$ BPE $17 \mu \mathrm{g} / \mathrm{mL}$ & 0,1 & 99,2 \\
Dox $2 \mu \mathrm{M}+$ BPE $34 \mu \mathrm{g} / \mathrm{mL}$ & 2 & 98,5 \\
\hline
\end{tabular}

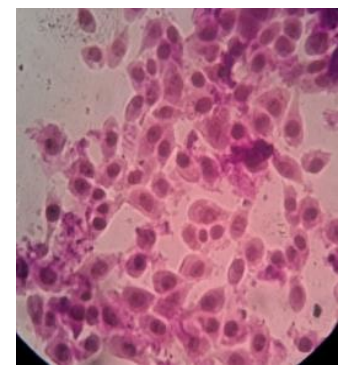

BPE $8.5 \mu \mathrm{g} / \mathrm{mL}$ (c)

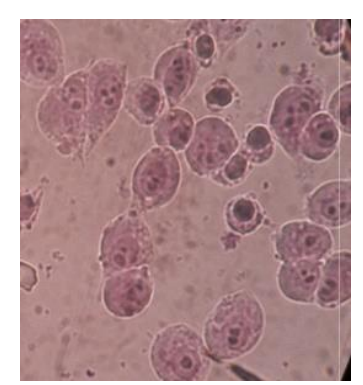

Dox $1 \mu \mathrm{M}+\mathrm{BPE} 8.5 \mu \mathrm{g} / \mathrm{mL}$

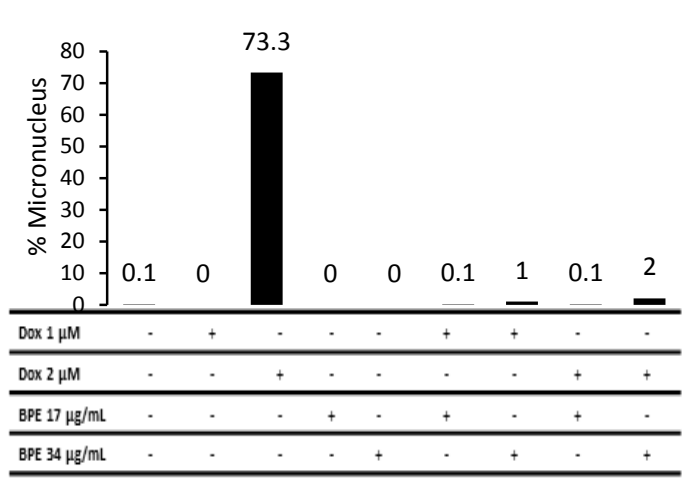

Figure 3. Effects of BPE administration on micronucleus formation in CHO-KI cells. CHO-KI cells of $12 \times 10^{3}$ cells/plants were seeded on coverslip within 24-wellplate for CBMN test and $5 \times 10^{4}$ cells/wells in 6-wellplate for genotoxic test with flowcytometry. Cells were treated with BPE, Dox, and their combination. (a) Cell morphology of $\mathrm{CHO}-\mathrm{KI}$ after being stained with Giemsa 5\%. The observation was done using light microscope with 400x magnification. (b) Percentage of micronucleus formation on CHO-KI cells.

\section{Molecular Interaction between Piperine and DNA Topoisomerase II}

Molecular docking was done to predict interaction of active compound in BPE toward DNA Topoisomerase II protein as the molecular target of Dox. Native ligand mitoxantron was used to compare the interaction of piperine on DNA Topoisomerase II protein. The lower docking score then easier to form bonding between ligand and protein target. Docking score of ligand and DNA Topoisomerase II was showed in Fig. 4a. The docking results showed piperine had lower affinity than mitoxantron on DNA Topoisomerase II protein because it had higher docking score than mitoxantron. Therefore, piperine could compete with mitoxantron in binding with DNA Topoisomerase II protein and might decrease the possibility of DNA damage. 
(a)

\begin{tabular}{ll}
\hline \multicolumn{1}{c}{ Ligand } & Docking score \\
\hline Native ligand (Mitoxantron) & $-109,51$ \\
\hline Doxorubicin & $-86,9733$ \\
\hline Piperin & $-80,6793$ \\
\hline
\end{tabular}

(b)

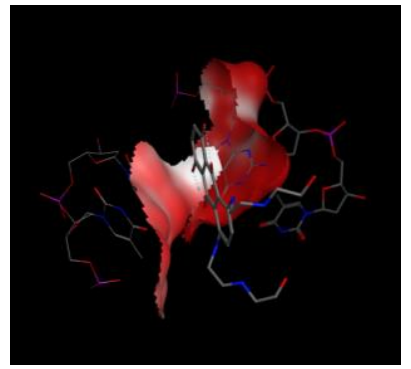

DNA Topoisomerase II mitoxantron

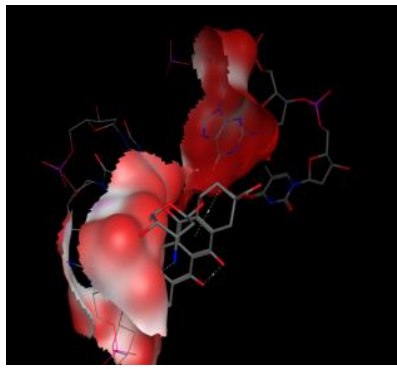

DNA Topoisomerase II doxorubicin

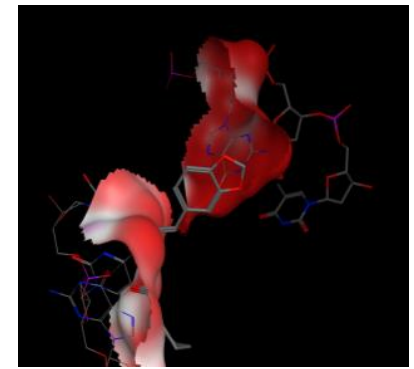

DNA Topoisomerase II -

Figure 4. Interaction between mitoxantron (native ligand), Dox, and piperine on DNA Topoisomerase II. Mitoxantron (native ligand), Dox, and piperine structures were prepared using MarvinSketch while DNA Topoisomerase II was prepared using YASARA. Docking simulation was performend using PLANTS software. (a) Docking score and (b) 3D visualization of interaction.

\section{DISCUSSION}

Genetic instability as an indicator of exposure to genotoxic agents is the common phenomena leading to the disease, included cancer. Dox is well known as the most common chemotherapeutic agent compared to another agent due to the strong cytotoxic activity (Cardoso, et al., 2009). However, Dox reported to possess genotoxicity that is caused by the produce of oxidative stress which reduces the activity of antioxidant, increase the lipid peroxidase and increase intracellular ROS level such as superoxide radical anion, hydroxyl radical, and singlet oxygen. This mechanism leads to the cell death and the micronucleus formation (Bryce, et al., 2010). Hence, an agent that possess strong cytotoxic activity as well as reduce the genotoxicity of doxorubicin are considered to develop a new cochemotherapeutic agent.

The results of our study showed that the single treatment of BPE reduced the viability of CHO-K1 cells in dose dependent manner and gave $\mathrm{IC}_{50}$ value of $68 \mu \mathrm{g} / \mathrm{mL}$. Based on Prayong, et al. (2008), the $\mathrm{IC}_{50}$ value of BPE on CHO-K1 cells was below $100 \mu \mathrm{g} / \mathrm{mL}$ meaning that BPE has strong cytotoxic activity. The result was in accordance with the previous studies, in which BPE was found to have cytotoxic activity on HeLa cell $(61.94 \pm 0.054$ $\mu \mathrm{g} / \mathrm{mL}$ ) (Paarakh, et al., 2015), 4T1 cells, and K562 cells (Lu, et al., 2012). The combination of BPE and Dox could also reduce cell viability with combination index $(\mathrm{CI})$ value of $<1$ which indicated synergistic activity between BPE and Dox (Fig. 2c). This data supported that BPE was potential to be developed as co-chemotheraetic agent in order to improve the effectiveness of Dox. Thus, we continued this research to investigate the genotoxicity of BPE in combination with Dox.

In the genotoxicity study, BPE showed antigenotoxic effect and provided protection against toxic and genotoxic effects induced by chemotherapeutic agent, Dox in in vitro system using CHO-K1 cell lines. There were no increases in the micronucleus-frequencies of the BPE treated group at doses of 17 and $34 \mu \mathrm{g} / \mathrm{mL}$. The reduction of micronucleus also seen in the combination with Dox compared to the positive control Dox itself (Fig. 3c). The results in the absence of micronucleus formation are in line with the previous literature data of piperine genotoxicity (Thiel, et al., 2014). To conclude on the cytotoxicity and genotoxicity potential of piperine, we considered all relevant data in several literatures: Piperine was tested under the Ames Test (Karekar, et al., 1996) and in vitro MNTs 
(Singh, et al., 1994), and showed negative results. Moreover, several studies at doses up to $75 \mathrm{mg} / \mathrm{kg}$ bw in different species showed the absence of micronucleus, DNA-strandbreaks, or dominant lethal mutation (Karekar, et al., 1996; Muralidhara and Narasimhamurthy, 1990; Selvendiran, et al., 2005; Balakrishnan, et al., 2008). In addition, several research strongly presented evidence for a chemopreventive activity of piperine rather than for a genotoxic activity (Vellaichamy, et al., 2009; Sehgal, et al., 2013). Furthermore, our result indicated that BPE performed antioxidant activity based on the reducing of intracellular ROS level on CHO-K1 cells compared to $\mathrm{H}_{2} \mathrm{O}_{2}$ treatment (Fig. $2 \mathrm{~d})$. This result enhanced the potency of BPE as antigenotoxic agent might be caused by neutralizing free radical compound which cause DNA damage.

These data suggested that BPE was not genotoxic, regardless of the concentration treatment. From the combination with Dox, BPE increased doxorubicin effectiveness and decreased the frequency of micronucleus, indicated that BPE reduced any toxic effects of Dox. Different mechanism of Dox and piperine might be contributed to the combinational cytotoxic effect of both. Dox interacts with DNA by intercalation and inhibits DNA Topoisomerase II. Therefore, we studied about the interaction between piperine and DNA Topoisomerase II using molecular docking. Molecular docking analysis demonstrated that piperine potentially inhibits the target protein, DNA Topoisomerase II. Although the docking score of piperine was lower than the native ligand, piperine could compete with Dox to interact with DNA Topoisomerase resulting in the increasing of doxorubicin effectiveness therapy. To confirm the anti-genotoxic effect of BPE should be conducted by mammalian in vivo micronucleus test and the others in vitro genotoxicity evaluation such as comet assay and DNA fragmentation assay to detect DNA damage. In addition, studies should be conducted to determine the limit dose in human consumption and provide rational concentration for implementing cochemotherapeutic and antigenotoxic agent.

\section{CONCLUSION}

We summarized that BPE was not induce micronucleus formation and could reduce the frequency of micronucleus induced by doxorubicin.
These results suggested that BPE has potency to be developed as an agent for preventing genetic damage. In addition, cytotoxic combination assay indicated that BPE might increase cytotoxic effect of doxorubicin on CHO-K1 cells. Therefore, BPE could be developed as co-chemotherapeutic agent to improve the effectiveness of doxorubicin therapy.

\section{ACKNOWLEDGMENT}

We express our gratitute to Directorate General of Learning and Student Affairs, Ministry of Research, Technology and Higher Education for the grant research under Student Creativity Program in 2016. We also thank to Prof. Masashi Kawaichi (NAIST Japan) for the CHO-K1 cells used in this research.

\section{REFERENCES}

Ahmad, N., Fazal, H., Abbasi, B. H., Farooq, S., Ali, M. and Khan, M. A., 20I2, Biological role of Piper nigrum L. (Black pepper): A review, Asian Pac. J. Trop. Biomed., 2(3), SI945-SI 953.

Andrews, A.W., Fornwald, J.A. and Lijinsky, W., 1980, Nitrosation and Mutagenicity of Some Amine Drugs, Toxicol. Appl. Pharmacol., 52(2), 237-244.

Avlasevich, S.L., Bryce, S.M., Cairns, S.E. and Dertinger, S.D., 2006, In Vitro Micronucleus Scoring by Flow Cytometry: Differential Staining of Micronuclei Versus Apoptotic and Necrotic Chromatin Enhances Assay Reliability, Environ. Mol. Mutagen., 47(I), 5666.

Bajad, S., Bedi, K.L., Singla, A.K. and Johri, R.K., 200I, Antidiarrhoeal Activity of Piperine in Mice, Planta Medica, 67(3), 284-287.

Balakrishnan, S., Vellaichamy, L., Menon, V.P. and Manoharan, S., 2008, Antigenotoxic Effects of Curcumin and Piperine Alone or in Combination Against 7,12dimethylbenz(a)anthracene Induced Genotoxicity in Bone Marrow of Golden Syrian Hamsters, Toxicol. Mech. Methods, I 8(9), 69|-696.

Bruton, L., Lazo, J.S. and Parker, K.L., 2005, Goodman \& Gilman's The Pharmacological Basis of Therapeutics, IIth Edition, Pennsylvania: McGrawHill.

Bryce, S.M., Shi, J., Nicolette, J., Diehl, M., Sonders, P., Avlasevich, S. and Dertinger, S.D., 2010, High Content Flow Cytometric Micronucleus 
Scoring Method is Applicable to Attachment Cell Lines, Environ. Mol. Mutagen., 5 I(3), 260266.

Carvalho, C., Santos, R.X., Cardoso, S., Correia, S., Oliveira, P.J., Santos, M.S., et al, 2009, Doxorubicin: The Good, the Bad and the Ugly Effect, Curr. Med. Chem., I6(25), 32673285.

Damanhouri, Z. A. and Ahmad, A., 2014, A Review on Therapeutic Potential of Piper nigrum L. (Black Pepper): The King of Spices, Med Aromat Plant, 3(3), I-6.

Fenech, M., 2000, The in Vitro Micronucleus Technique, Mutat. Res. Fundam. Mol. Mech. Mutagen., 455(I), 8I-95.

Gülçin, İ., 2005, The Antioxidant and Radical Scavenging Activities of Black Pepper (Piper nigrum) Seeds, Int. J. Food Sci. Nutr., 56(7), 49I-499.

Karekar, V.R., Mujumdar, A.M., Joshi, S.S., Dhuley, J., Shinde, S.L. and Ghaskadbi, S., 1996, Assessment of Genotoxic Effect of Piperine using Salmonella typhimurium and Somatic and Germ Cells of Swiss Albino Mice, Arzneimittel-Forschung/Drug Res., 46(10), 972975.

Khan, M., Maryam, A., Mehmood, T., Zhang, Y. and Ma, T., 2015, Enhancing Activity of Anticancer Drugs in Multidrug Resistant Tumors by Modulating P-Glycoprotein through Dietary Nutraceuticals, Asian Pac. J. Cancer Prev., I6(16), 683 I-6839.

Li, S., Wang, C., Wang, M., Li, W., Matsumoto, K. and Tang, Y., 2007. Antidepressant Like Effects of Piperine in Chronic Mild Stress Treated Mice and Its Possible Mechanisms, Life Sci., 80(I5), I373-I38I.

Lu, J.J., Bao, J.L., Chen, X.P., Huang, M. and Wang, Y.T., 20I2, Alkaloids Isolated from Natural Herbs as The Anticancer Agents, Evid. Based Complement. Alternat. Med., 2012, 485042, doi: I0.I I55/2012/485042.

Manoharan, S., Balakrishnan, S., Menon, V., Alias, L. and Reena, A., 2009, Chemopreventive Efficacy of Curcumin and Piperine during 7,I2-dimethylbenz[a]anthracene-induced Hamster Buccal Pouch Carcinogenesis, Singapore Med. J., 50(2), I39-I46.

Meghwal, Murlidhar and Goswami., T.K., 20I3, Piper nigrum and Piperine: An Update, Phytother. Res., 27(8), I I 2 I- I I 30.

Mosmann, T., 1983, Rapid Colorimetric Assay for cellular growth and Survival: Application to Proliferation and Cytotoxicity Assays, J. Immunol. Methods., 65(I-2), 65-59.
Muralidhara and Narasimhamurthy, K., 1990, Lack of Genotoxic Effects of Piperine, (The Active Principle of Black Pepper) in Albino Mice, J. Food Saf., I I ( I), 39-48.

Paarakh, P.M., Sreeram, D.C., Shruthi, S.D. and Ganapathy, P.S., 2015, In Vitro Cytotoxic and in Silico Activity of Piperine Isolated from Piper nigrum fruits Linn, In Silico Pharmacology, 3(I), 9.

Parganiha, R., Verma, S., Chandrakar, S., Pal, S., Sawarkar, H.A. and Kashyap, P., 20II, In Vitro Anti-asthmatic Activity of Fruit Extract of Piper nigrum (Piperaceae), Inter. J. Herbal Drug Res., I(I), I5-18.

Prayong, P., Barusrux, S. and Weerapreeyakul, N., 2008, Cytotoxic Activity Screening of Some Indigenous Thai Plants, Fitoterapia, 79(7), 598601 .

Rasheed, M., Afshan, F., Tariq, R.M., Siddiqui, B.S., Gulzar, T., Mahmood, A., et al, 2005, Phytochemical Studies on The Seed Extract of Piper nigrum Linn., Nat. Prod. Res., 19(7), 703-7I2.

Sehgal, A., Kumar, M., Jain, M. and Dhawan, D.K., 2013, Modulatory Effect of Curcurmin in Conjunction with Piperine on benzo(A)pyrene-mediated DNA Adducts and Biotransformation Enzymes, Nutr. Cancer, 65(6), 885-890.

Selvendiran, K., Singh, J.P.V., Krishnan, K.B. and Sakthisekaran, D., 2003, Cytoprotective Effect of Piperine against Benzo[a]pyrene Induced Lung Cancer with Reference to Lipid Peroxidation and Antioxidant System in Swiss Albino Mice, Fitoterapia, 74( I-2), I09-I I5.

Singh, J., Reen, R.K. and Wiebel, F.J., 1994, Piperine, A Major Ingredient of Black and Long Peppers, Protects Against AFBI-induced Cytotoxicity and Micronuclei Formation in H4IIEC3 Rat Hepatoma Cells, Cancer Lett., 86(2), 195-200.

Taqvi, S.I., Shah, A.J. and Gilani, A.H., 2008, Blood Pressure Lowering and Vasomodulator Effects of Piperine, J. Cardiovasc. Pharmacol., 52(5), 452-458.

Thiel, A., Buskens, C., Woehrle, T., Etheve, S., Schoenmakers, A., Fehr, M., et al., 2014, Black Pepper Constituent Piperine: Genotoxicity Studies in Vitro and in Vivo, Food Chem. Toxicol., 66, 350-357.

Vellaichamy, L., Balakrishnan, S., Panjamurthy, K., Manoharan, S. and Alias, L.M., 2009, Chemopreventive Potential of Piperine in 7, I2-dimethylbenz[a]anthracene-induced Skin Carcinogenesis in Swiss Albino Mice, Environ. Toxicol. Pharmacol., 28(I), I I-I8. 